\title{
Performance Analysis of Grid Integrated Hydro and Solar Based Hybrid Systems
}

\author{
Sweeka Meshram, Ganga Agnihotri, and Sushma Gupta \\ Department of Electrical Engineering, Maulana Azad National Institute of Technology (MANIT), Bhopal 462051, India \\ Correspondence should be addressed to Sweeka Meshram; sweekam@gmail.com
}

Received 20 January 2013; Revised 16 May 2013; Accepted 30 May 2013

Academic Editor: Pavol Bauer

Copyright ( 2013 Sweeka Meshram et al. This is an open access article distributed under the Creative Commons Attribution License, which permits unrestricted use, distribution, and reproduction in any medium, provided the original work is properly cited.

\begin{abstract}
The renewable energy systems (RESs) are an attractive option to electrify the community as they are environment friendly, free of cost, and all-pervading. The efficiency of these energy systems is very low and can be improved by integrating them in parallel. In this paper, hydro $(7.5 \mathrm{~kW})$ and solar systems $(10 \mathrm{~kW})$ are taken as RESs and connected with the utility grid. Due to the intermittent nature of both the hydro and photovoltaic energy sources, utility grid is connected to the system for ensuring the continuous power flow. The hydro power generation system uses the self excited induction generator (SEIG) and converters. The AC/DC/AC converter is used as interface to connect the hydro turbine to the utility grid to adjust the generated voltage to the utility grid voltage. The solar generation system is the combination of PV array, boost converter, and solar inverter. The control of both the hydro and solar power plants is provided through the constant current controller. The analysis has been done to verify the existence of the proposed system. Results demonstrate that the proposed system is able to be put into service and can feed the community.
\end{abstract}

\section{Introduction}

Electricity requirement is increasing day by day all over the world. The power generation of electrical energy to fulfill the power requirement is mainly done with the use of fossil fuels such as oil, coal, and gas. The conventional scheme of power generation may cause depletion of the fossil fuel and degradation of environment. Because of this, the researchers are envisaging the power generation technique from the renewable energy sources such as solar, hydro, wind, and biomass. These energy sources are most efficient to be preferred for distribution generation (DG) system as they are abundantly, economically, and easily available. Such types of DGs have less cost with easy and less expensive maintenance [1].

Recently, solar systems are seeking more attention as solar energy is omnipresent, and cost of photovoltaic (PV) cell is reducing nowadays. The PV systems are intermittent in nature and cannot satisfy the power requirement alone throughout the year. Hence, mostly the grid integrated PV system with advancement is preferred to ensure the continuous power flow [2-8]. The mini/micro hydro systems are also getting interest to generate the electrical power in remote/rural areas. The standalone hydro system with smaller sizes uses self-excited induction generator (SEIG). The SEIG is maintenance free, rugged in construction, has good conversion efficiency, and is self-protected against fault [9]. The limitation with the hydro system is its poor voltage and frequency regulation. Therefore, a reliable technique is required to maintain constant voltage and frequency irrespective of the load and load types. Various controllers have been reported in [10-12], but these controllers may raise the cost and complexity. Improving the performance of the hydro system grid may also be integrated.

Both renewable energy systems cannot fulfill the power requirement alone as they are intermittent in nature. The only solution to this problem is the hybrid energy system. Some common used hybrid energy systems are solar wind, wind hydro, wind diesel, solar thermal biomass, and so forth [13-15]. Recently, the researchers are investigating on solar and hydro based hybrid energy systems [16, 17]. This hybrid energy system can be implemented to those areas, where solar and hydro resources are moderate in nature. The problem with this hybrid system is that hydro and solar systems cannot 


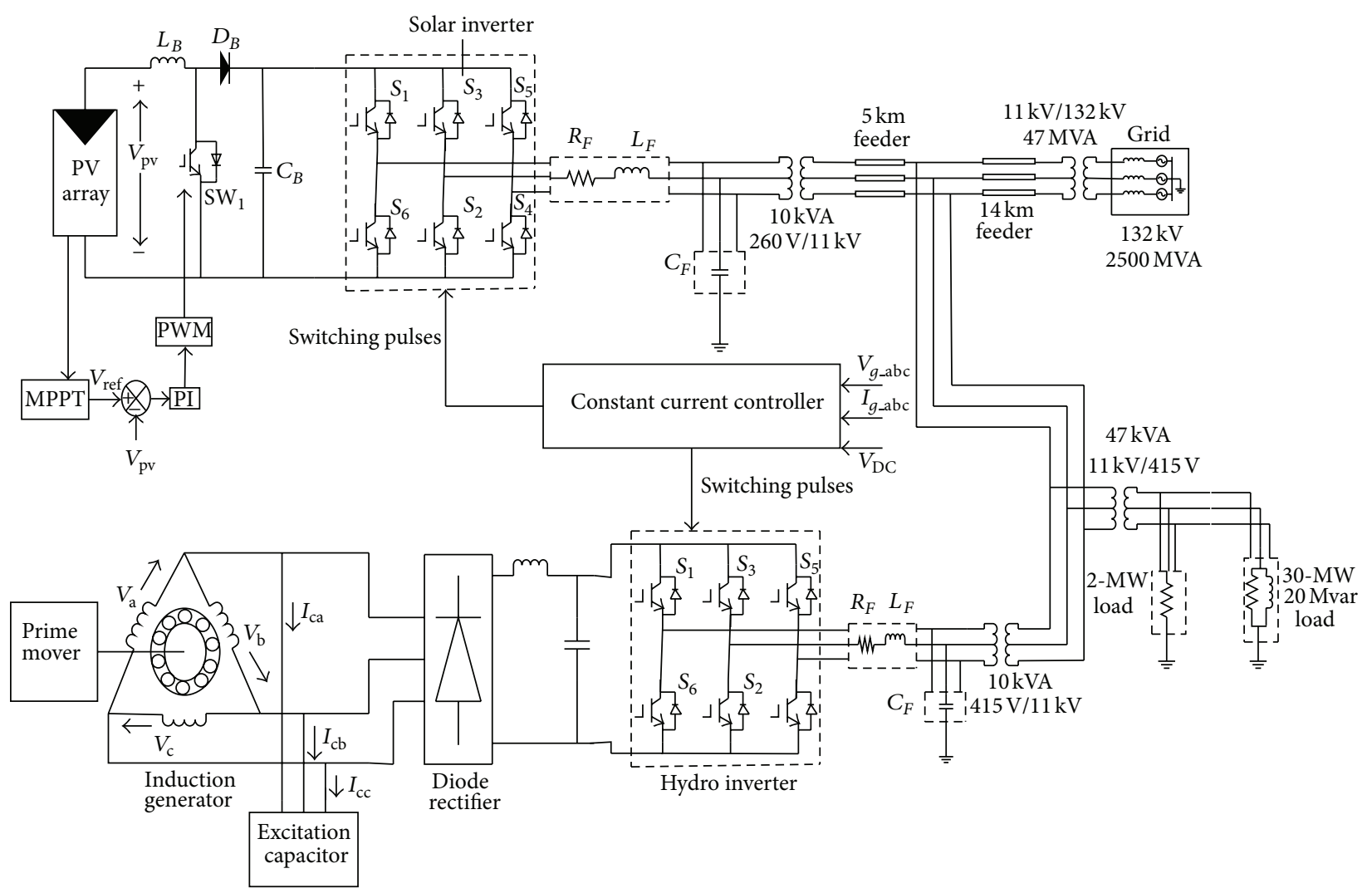

FIGURE 1: Schematic diagram of grid integrated hydro and solar based hybrid energy system.

generate the power simultaneously in summer/rainy days as one of them will not be able to generate power. To satisfy the power requirement, integration of the power grid or diesel generator is required. For supplying electric power in rural areas using this hybrid system, the power grid may be integrated, and for supplying remote/isolated areas diesel generator may be incorporated as a backup.

In this paper, a system is proposed in which hydro and solar based hybrid power generation system is connected with the utility grid. In the peak summer, solar energy is abundantly available, but in rainy days it is difficult to generate the electrical power using the solar energy. Similarly the power generation using the hydro energy gives better efficiency in rainy seasons. Hence, the parallel combination of these two energy systems has been adopted, and for the continuous power flow grid is also connected. In the summer, the grid connected solar system supplies the power to the load, and hydro system will be disconnected. In rainy days the grid connected hydro system supplies the power to the load, and solar system will be disconnected. In other seasons, grid connected the solar and hydro systems are able to deliver the power to the consumer. Hence, it is good option to adopt the proposed system for supplying continuous power to the consumer. The solar power generation system contributes power of about $10 \mathrm{~kW}$. It consists of PV array, DC-DC boost converter, and solar inverter controlled by constant current controller. The hydro system have the self-excited induction generator (SEIG) and back to back converter (combination of Rectifier and inverter) as an interfacing device for integrating the hydro system into the utility grid. The hydro power generation system contributes $7.5 \mathrm{~kW}$ power.

\section{System Description}

Figure 1 shows the circuit diagram of the grid connected solar and hydro based hybrid energy systems. A $10 \mathrm{~kW}$ PV array and a $7.5 \mathrm{~kW}$ self-excited induction generator are connected to the $132 \mathrm{kV}, 2500$ MVA utility grid. The detailed description is given as follows.

2.1. Solar System. The solar system consists of PV array, boost converter, solar inverter with a harmonic reduction LC filter. The PV array is delivering $10 \mathrm{~kW}$ at $1000 \mathrm{~W} / \mathrm{m}^{2}$ solar irradiation. The DC power generated by the PV array charges the DC link capacitor. The PV array can be mathematically modeled as

$$
P_{\mathrm{pv}}=I_{\mathrm{pv}} V_{\mathrm{pv}}=N_{P} I_{\mathrm{ph}}\left[\left(\frac{q}{k A T} * \frac{V_{\mathrm{pv}}}{N_{S}}\right)-1\right],
$$

where $P_{\mathrm{pv}}$ is generated DC power of the PV array $(\mathrm{kW}), V_{\mathrm{pv}}$ and $I_{\mathrm{pv}}$ are generated DC Voltage (in V) and current (in A) of the PV array, respectively. $I_{\mathrm{ph}}$ is photocurrent of the PV cell (5.96 A), $q$ is charge of an electron, that is, $1.602 \times 10^{-19} \mathrm{C}$, $A$ is ideality factor, that is, $2.46, T$ is cell temperature $(\mathrm{K}), N_{S}$ is number of series connected PV modules. $N_{P}$ is number of parallel connected PV modules.

The boost converter increases voltage level from the PV natural DC voltage to the desired DC voltage. The output 


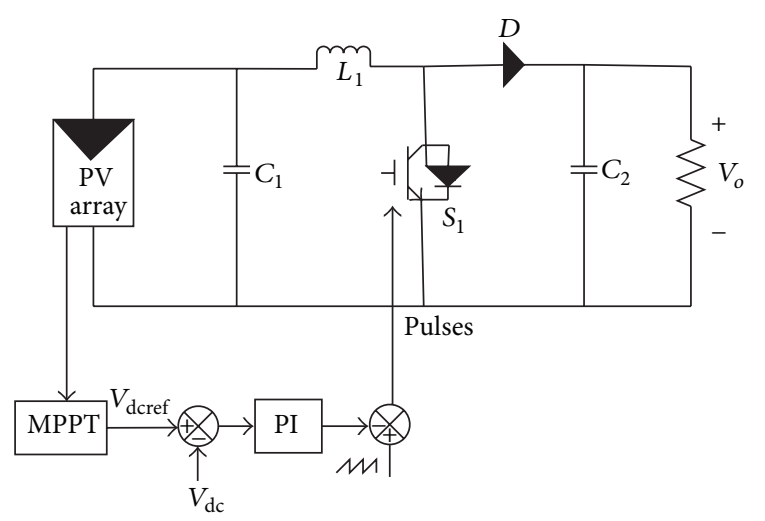

Figure 2: Controller for DC-DC converter.

voltage of the PV cell is very limited, which is very low for the application. The series and parallel combination also do not provide the required output. Hence, the boost converter is necessary to boost the low output voltage of PV array. A capacitor is also connected for reducing the high frequency harmonics between the PV array and boost converter. Figure 2 shows the closed loop controller for boost converter. Switching duty cycle of the boost converter is optimized by the MPPT controller that uses the incremental conductance technique. The control of the boost converter is provided through the PWM signal. The output of the filter which is the control signal is compared with the reference voltage. The PI controller attempts to minimize the error by adjusting the process control inputs. Then it is compared with the saw-tooth waveform to generate the PWM signal which is fed as a gate signal to the IGBT switch. Thus, the PV array can be controlled by controlling the duty ratio for operating at the maximum power point.

The voltage source converter inverts the DC voltage to the sinusoidal AC voltage keeping the unity power factor. The control of the solar inverter is provided through the constant current controller. The harmonics produced by the VSC is filtered by the LC filter. To integrate the PV system with the utility grid, the AC voltage level has been stepped up to the grid voltage level using a $10 \mathrm{kVA}$ transformer. This transformer also performs as an isolation transformer.

2.2. Hydro System. The hydro system consists of self-excited induction generator (SEIG), back to back converter (combination of rectifier and inverter), and LC filter. An externally hydro turbine driven induction machine is operated as a SEIG with its excitation requirement supplied by the 3- $\Phi$ capacitor bank at no load. The power generated by the SEIG is fed to the utility grid through the back to back converter via common DC link. The generator side converter acts as a rectifier and used to convert variable magnitude and variable frequency voltage at SEIG terminals to the DC voltage. The grid side converter works as a PWM inverter. The DC power available at the rectifier output is filtered using the LC filter and converted to AC power using a PWM inverter. The hydro PWM inverter is also controlled using the current controller. The output of the PWM inverter contains the harmonics and is filtered using the LC filter. For connecting the hydro system to the grid, the voltage level of the hydro system is increased from $415 \mathrm{~V}$ to $11 \mathrm{kV}$ using the $10 \mathrm{kVA}$ three-phase two-winding transformer.

\section{Controller for the Inverter}

In the proposed grid connected hydro and solar systems, the $3-\Phi$ inverter is interfacing the utility grid and also converts the variable direct current output of a photovoltaic $(\mathrm{PV})$ panel into a utility frequency alternating current that can be fed into a commercial electrical grid. It is a critical component in the system, and its control should be such that its output can interface the voltage of the utility grid. For connecting the solar and hydro system in parallel with the grid, it is essential that the voltage magnitude, frequency, and phase sequences of both the energy system and power grid must be same. This feature is provided through the constant current controller (CCC). CCC generates the switching pulses for solar and hydro side interfacing inverter such that the frequency and phase sequences of output voltages of the inverters are the same as of the grid voltage.

In this proposed system, two inverters are used: one is for integrating solar system into grid, that is, solar inverter, and another is for integrating the hydro system, that is, hydro inverter. There are two basic control modes for the grid connected inverters. One constant current control and the other is constant power control. In this proposed model, the control of the solar inverter is provided through the constant current controller using the 3- $\Phi$ phase locked loop (PLL). In constant current control, the inverter output currents are regulated to the reference grid current.

Figure 3 shows the detailed block diagram of the constant current controller for generating the controlled switching pulses for the solar inverter such that the output voltage should be able to interface the grid. The 3- $\Phi$ phase locked loop calculates the phase angle of the utility grid and also gives the information about the frequency variation. According to the phase angle of the utility grid voltage, the constant current controller is modeled such that the controller is able to generate the switching pulses for solar and hydro inverter for tracking the phase of the grid voltage. The 3- $\Phi$ grid current $I_{\text {gabc }}$ is converted into $\alpha \beta$ variable using the Clarke transformation. The $\alpha \beta$ variables are transformed into the dq variables. The current, $I_{d}$ and $I_{q}$ are compared with the $I_{\text {dref }}$ and $I_{\text {qref }}$ for processing in the PI controller to minimize the errors. These signals are transformed into 3- $\Phi$ signal using the inverse park's transform and then compared with the triangular waveform for generating the PWM switching pulse for the solar inverter. The $V_{\mathrm{dc}}$ and $V_{\mathrm{dcref}}$ are the DC link voltage of the PV array for the solar system or DC link voltage of rectifier for the hydro system and expected DC voltage of the PV array or the rectifier for solar or hydro systems respectively.

\section{Modeling of System}

The $132 \mathrm{kV}, 2500$ MVA utility grid is connected to $10 \mathrm{~kW}$ PV system and also with the $7.5 \mathrm{~kW}$ hydro system. The 


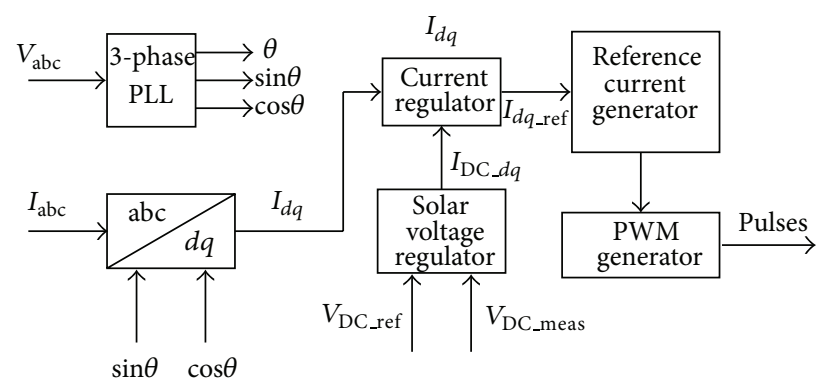

(a) Control unit

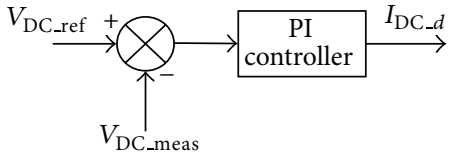

(b) Voltage regulator

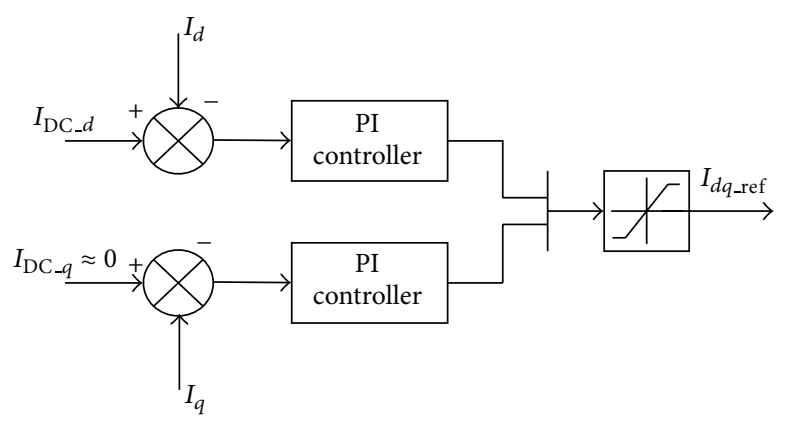

(c) Current regulator

FIGURE 3: Block diagram of constant current controller.

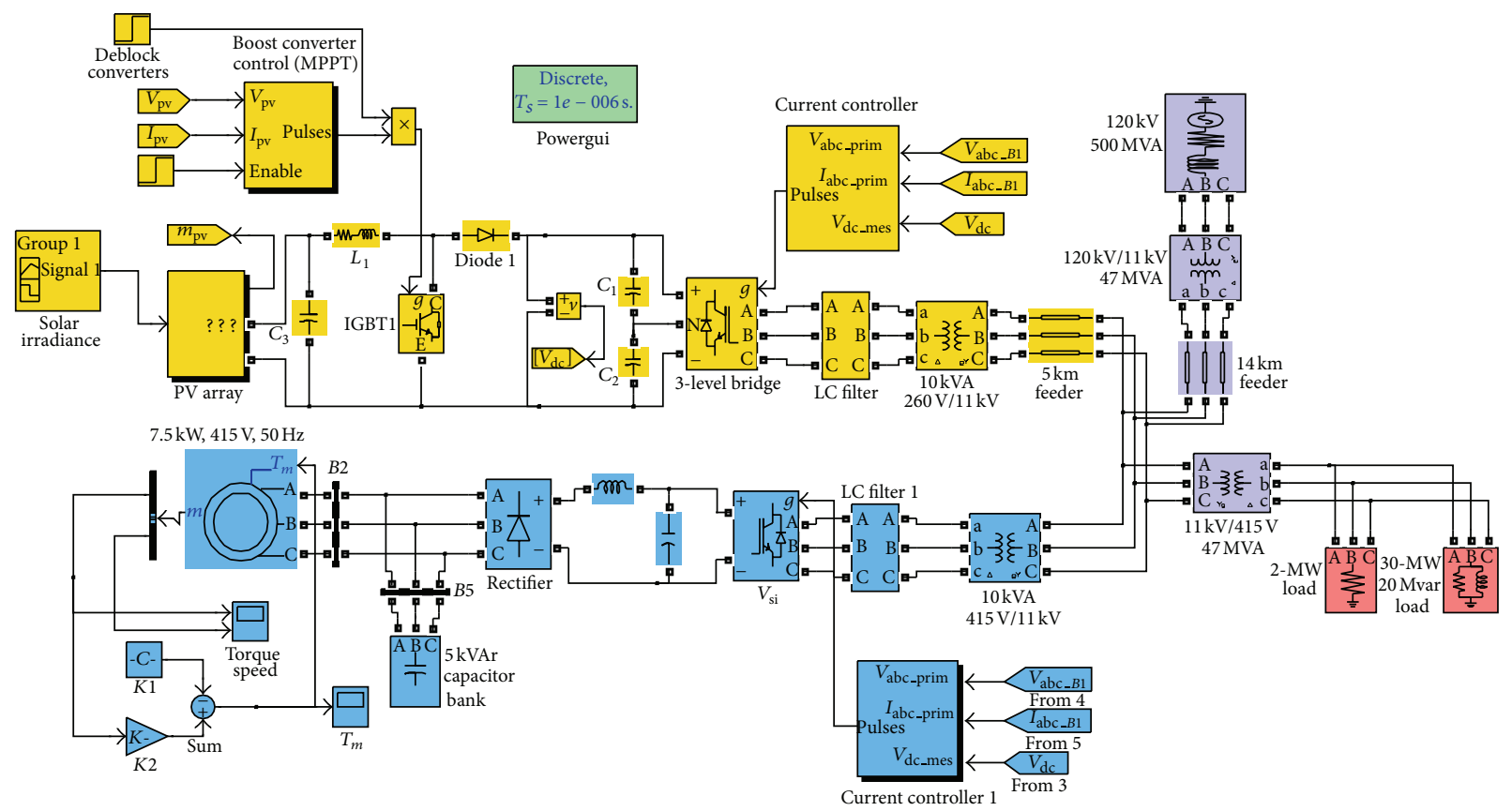

FIGURE 4: MATLAB simulink model of the grid integrated hydro and solar based hybrid systems.

array consists of 8 strings of 5 series connected PV modules connected in parallel. One PV module has $96 \mathrm{PV}$ cells. The $\mathrm{PV}$ array is delivering the $10 \mathrm{~kW}$ at $1000 \mathrm{~W} / \mathrm{m}^{2}$ at maximum power. The open circuit voltage $\left(V_{\mathrm{OC}}\right)$ of the one module is $64.2 \mathrm{~V}$, and voltage at the maximum power point $\left(V_{\mathrm{mp}}\right)$ is $54.7 \mathrm{~V}$. The short circuit current $\left(I_{\mathrm{SC}}\right)$ of the one module is
$5.96 \mathrm{~A}$, and current at the maximum power point is $5.58 \mathrm{~A}$. The $5 \mathrm{kHz}$ boost converter increases the PV natural DC voltage $(300 \mathrm{~V})$ to the $500 \mathrm{~V}$ DC voltage. For smoothing the DC voltage LC filter is used. The value of smoothing inductor and capacitor is chosen as $L_{S 1}=200 \mu \mathrm{H}$ and $C_{S 1}=5000 \mu \mathrm{F}$. The three-phase voltage source inverter 


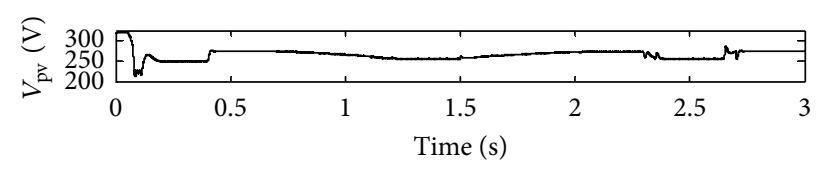

(a)

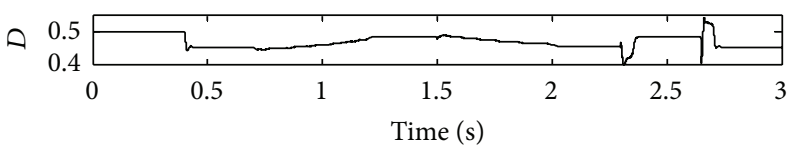

(b)

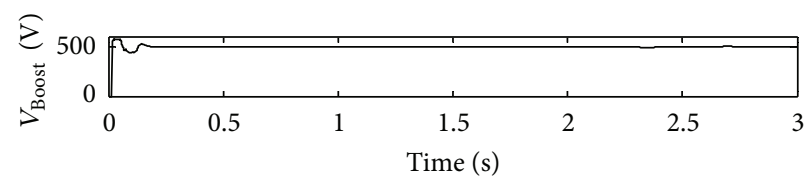

(c)

FIGURE 5: Output voltage, duty ratio of PV array and output voltage of the boost converter.

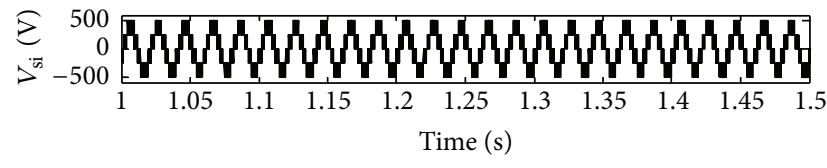

(a)

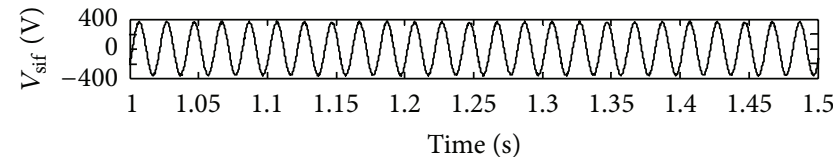

(b)

FIGURE 6: Inverter output voltage before and after filtering.

converts $500 \mathrm{~V}$ DC voltage to the $415 \mathrm{~V}$ AC voltage. The switching frequency of the solar inverter is $1080 \mathrm{~Hz}$. The obtained AC voltage is in stepped waveform. Hence, the 3$\Phi$ LC filter is used for converting the stepped waveform into the pure sinusoidal waveform. The filtering inductance has been chosen as $L_{F 1}=200 \mathrm{mH}$ with small series resistance valued as 0.002, and filtering capacitor bank of $5 \mathrm{kVAr}$ is used. To avoid resonance problem, the damping resistor is used in series with the filtering capacitor bank $C_{F 1}$, which can absorb the switching frequency ripple and is valued as $2 \Omega[18,19]$. A $10 \mathrm{kVA}$ transformer is used to increase the AC voltage level from $260 \mathrm{~V}$ to the grid voltage level $11 \mathrm{kV}$. Figure 4 shows the MATLAB simulink model for the grid integrated hydro and solar based hybrid systems.

The $7.5 \mathrm{~kW}$ induction machine is used as self-excited induction generator (SEIG). The initial excitation requirement of the SEIG is met by the $5 \mathrm{kVAr}$ capacitor bank. For feeding the AC power to the utility grid, the back to back (AC-DC-AC) converter is used. The AC voltage generated by the induction generator is converted to the $\mathrm{DC}$ voltage using the uncontrolled rectifier. The output of the rectifier contains the ripples. For obtaining the ripple free DC voltage LC filter is used with the value of $L_{S 2}=1 \mathrm{mH}$ and $C_{S 2}=5 \mathrm{mF}$. The grid side converter acts as a PWM inverter, whose control is provided through the CCC. The $3-\Phi$ LC filter is sinusoidal AC voltage. The numeric value of the inductance $L_{F 2}=0.205 \mathrm{H}$ with the series resistance of $0.001 \Omega$ and the filtering capacitor bank of $5 \mathrm{kVAr}$ with the series damping resistance $R_{D 2}=$ $5 \Omega$ has been calculated $[18,19]$. For the isolation as well as increasing the voltage level from $415 \mathrm{~V}$ to $11 \mathrm{kV}$ AC voltage a $10 \mathrm{kVA}$ three-phase two-winding transformer is used. The grid connected hydro and solar systems are able to feed the static resistive and $\mathrm{R}-\mathrm{L}$ load.

\section{Results and Discussion}

5.1. Results of Solar System. The PV array generates $10 \mathrm{~kW}$ at $1000 \mathrm{~W} / \mathrm{m}^{2}$ solar radiation. The generated DC voltage is very low for the application and also varies with the temperature and solar irradiation. Figure 5(a) shows the variation in the generated $\mathrm{PV}$ array voltage $\left(V_{\mathrm{pv}}\right)$ due to variation in the temperature and solar irradiation. Figure 5(b) shows the variation in the duty ratio $(D)$ of the boost converter to keep the output voltage constant with the variable input PV array voltage. The MPPT is enabled at 0.4 second. Figure 5(c) depicts the output voltage $\left(V_{\text {Boost }}\right)$ of the boost converter.

The $500 \mathrm{~V}$ constant DC voltage is converted into $260 \mathrm{~V}$, $50 \mathrm{~Hz}$ AC voltage using bridge inverter. Figure 6(a) shows the output voltage $\left(V_{\mathrm{si}}\right)$ of the inverter before filtering. Passive filter is used to reduce the harmonic content of the inverter output voltage. Figure $6(\mathrm{~b})$ shows the output voltage $\left(V_{\text {sif }}\right)$ of the inverter after filtering.

5.2. Results of Hydro System. The SEIG is generating the $415 \mathrm{~V}$ AC voltage with the initial excitation being met by capacitor bank. The SEIG is taking $1.0 \mathrm{sec}$ for generating the AC power. The uncontrolled rectifier is connected at the SEIG terminals to convert the AC voltage into DC voltage. Figure 7(a) shows the stator voltage $\left(V_{s}\right)$ of SEIG. Figure $7(\mathrm{~b})$ shows the output DC voltage $\left(V_{\text {hdc }}\right)$ of the rectifier before filtering. To obtain the smooth DC voltage the LC filter is used. Figure 7(c) shows the output DC voltage $\left(V_{\text {hdcf }}\right)$ of the rectifier after filtering.

The DC voltage is converted into AC using the PWM inverter. Figure $8(\mathrm{a})$ shows the output AC voltage $\left(V_{\mathrm{h}}\right)$ of the hydro inverter before filtering. The LC filter is used for making the pure sinusoidal waveform of the hydro inverter. Figure $8(\mathrm{~b})$ shows the output AC voltage $\left(V_{\mathrm{hf}}\right)$ of the hydro inverter after filtering. 


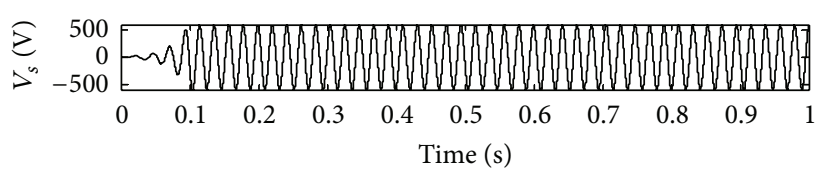

(a)

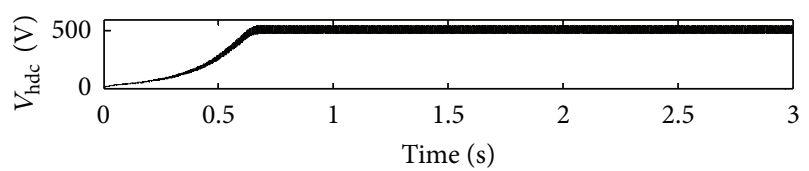

(b)

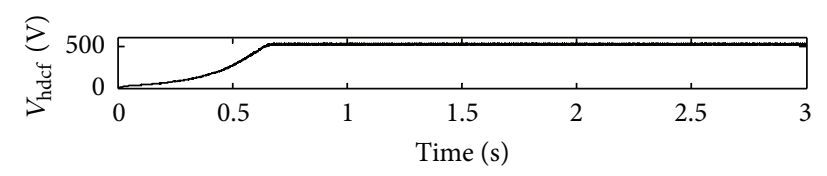

(c)

Figure 7: Output of the hydro system.

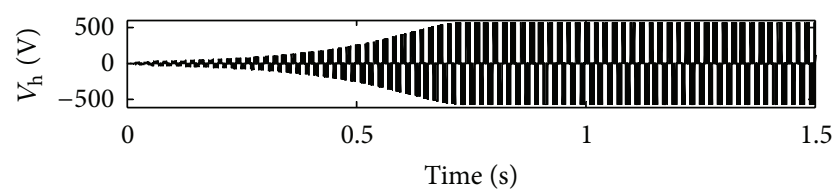

(a)

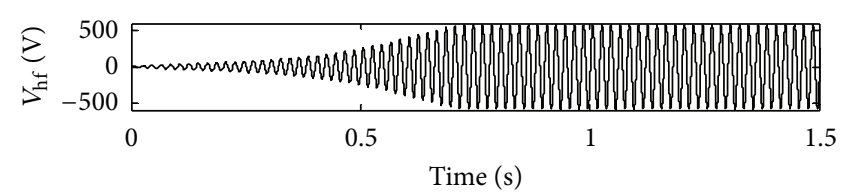

(b)

FIgURE 8: Output AC voltage of the hydro inverter before and after filtering.

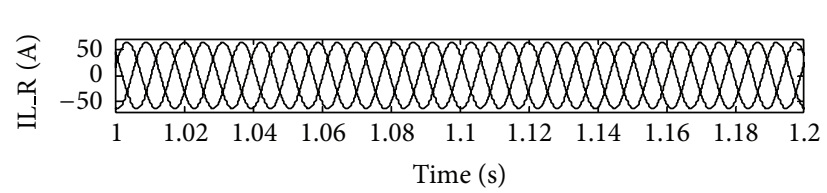

(a)

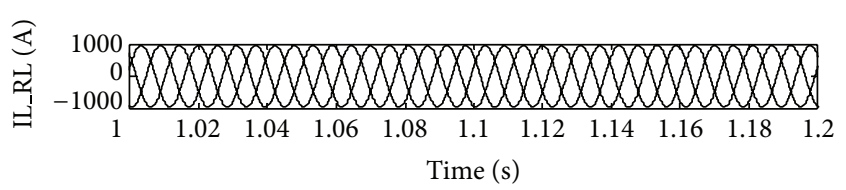

(b)

FIgURE 9: Load current through resistive and RL load.

The solar and hydro system is integrated into a $132 \mathrm{kV}$, 2500 MVA utility. A 47 MVA, $132 \mathrm{kV} / 11 \mathrm{kV}$ step-down transformer is used for bringing the AC voltage level to the level of hydro and solar system voltage for connecting in parallel. Resistive load of $2 \mathrm{MW}$ and RL load of $30 \mathrm{MW}$ (0.8 lagging power factor) are supplied through the proposed model. Figures 9(a) and 9(b) show the load current waveforms (IL_R and IL_RL in Amp) for the linear resistive and RL load, respectively.

\section{Conclusion}

In this paper, analysis of grid interactive solar and hydro systems has been done. The proposed system is implementable to those areas where the solar and hydro energies are available at moderate nature such as Indian circumstance. The nature of the solar and hydro energies is intermittent. Hence, using the individual system the continuous power generation is not possible, and it will also increase burden to the grid. The proposed system is able to supply the community in all seasons. In rainy season, the grid connected hydro system will feed the AC power to the consumers and in summer grid connected solar system will supply power. In other season both systems will supply the power to the consumer. The proposed system reduces the complexity of the electrical system, having less cost as compared to other RESs and reliable operation. The control of interfacing solar and hydro inverters is provided through the constant current controller. As compared to phase and amplitude control, constant current controller offers reduced cross-coupling between the real and reactive power control loops, greater immunity to phase measurement errors, better transient response, reduced current harmonics, and inherent overcurrent protection. The obtained results show that the proposed system has the potential to supply the local community.

\section{References}

[1] V. Verma, P. Pant, and B. Singh, "Indirect current controlled VSC for reactive power and load control support to self-excited induction generator feeding 3-phase 4-wire isolated power system," in Proceedings of the Joint International Conference on Power Electronics, Drives and Energy Systems (PEDES '10), December 2010.

[2] H. Yu, J. Pan, and A. Xiang, "A multi-function grid-connected PV system with reactive power compensation for the grid," Solar Energy, vol. 79, no. 1, pp. 101-106, 2005.

[3] N. Srisaen and A. Sangswang, "Effects of PV grid-connected system location on a distribution system," in Proceedings of the 
IEEE Asia Pacific Conference on Circuits and Systems (APCCAS '06), pp. 852-855, December 2006.

[4] J. H. So, Y. S. Jung, G. J. Yu, J. Y. Choi, and J. H. Choi, "Performance results and analysis of $3 \mathrm{~kW}$ grid-connected PV systems," Renewable Energy, vol. 32, no. 11, pp. 1858-1872, 2007.

[5] R.-J. Wai and W.-H. Wang, "Grid-connected photovoltaic generation system," IEEE Transactions on Circuits and Systems I, vol. 55, no. 3, pp. 953-964, 2008.

[6] S.-K. Kim, J.-H. Jeon, C.-H. Cho, E.-S. Kim, and J.-B. Ahn, "Modeling and simulation of a grid-connected PV generation system for electromagnetic transient analysis," Solar Energy, vol. 83, no. 5, pp. 664-678, 2009.

[7] S. Meshram, G. Agnihotri, and S. Gupta, "An efficient constant current controller for PV Solar Power Generator integrated with the grid," in Proceedings of the IEEE 5th Power India Conference (PICONF '12), December 2012.

[8] S. Meshram, G. Agnihotri, and S. Gupta, "A modern two dof controller for grid integration with solar power generator," International Journal of Electrical Engineering \& Technology, vol. 3, no. 3, pp. 164-174, 2012.

[9] B. Singh, "Induction generator-a prospective," Electric Machines and Power Systems, vol. 23, pp. 163-177, 1995.

[10] B. Singh, S. S. Murthy, and S. Gupta, "Analysis and design of STATCOM-based voltage regulator for self-excited induction generators," IEEE Transactions on Energy Conversion, vol. 19, no. 4, pp. 783-790, 2004.

[11] B. Singh, S. S. Murthy, and S. Gupta, "Analysis and implementation of an electronic load controller for a self-excited induction generator," IEE Proceedings: Generation, Transmission and Distribution, vol. 151, no. 1, pp. 51-60, 2004.

[12] B. Singh, S. S. Murthy, and S. Gupta, "Analysis and design of STATCOM-based voltage regulator for self-excited induction generators," IEEE Transactions on Energy Conversion, vol. 19, no. 4, pp. 783-790, 2004.

[13] C. Wang and M. H. Nehrir, "Power management of a standalone wind/photovoltaic/fuel cell energy system," IEEE Transactions on Energy Conversion, vol. 23, no. 3, pp. 957-967, 2008.

[14] T. Hirose and H. Matsuo, "Standalone hybrid wind-solar power generation system applying dump power control without dump load," IEEE Transactions on Industrial Electronics, vol. 59, no. 2, pp. 988-997, 2012.

[15] T. K. Saha and D. Kastha, "Design optimization and dynamic performance analysis of a stand-alone hybrid wind-diesel electrical power generation system," IEEE Transactions on Energy Conversion, vol. 25, no. 4, pp. 1209-1217, 2010.

[16] A. Beluco, P. K. Souza, and A. Krenzinger, "PV hydro hybrid systems," IEEE Latin America Transactions, vol. 6, no. 7, pp. 626631, 2008.

[17] S. Meshram, G. Agnihotri, and S. Gupta, "Design of hydro and solar energy-hybrid system for remote areas," in Proceedings of the International Conference on Electrical and Electronics Engineering (ICEEE '11), vol. 2, October 2011.

[18] Y. Lang, D. Xu, S. R. Hadianamrei, and H. Ma, "A Novel design method of LCL type utility interface for three-phase voltage source rectifier," in Proceedings of the International Conference on Power Electronics Specialists Conference, pp. 313-317, 2005.

[19] H. Cha and T.-K. Vu, "Comparative analysis of low-pass output filter for single-phase grid-connected photovoltaic inverter," in Proceedings of the 25th Annual IEEE Applied Power Electronics Conference and Exposition (APEC '10), pp. 1659-1665, February 2010 . 

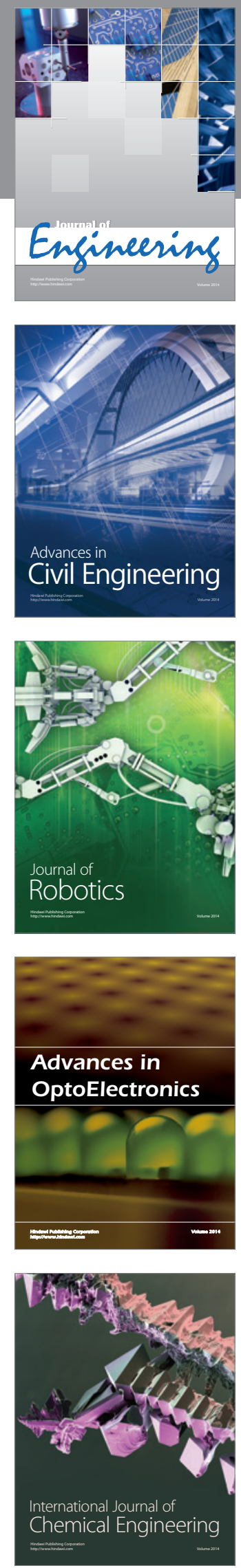

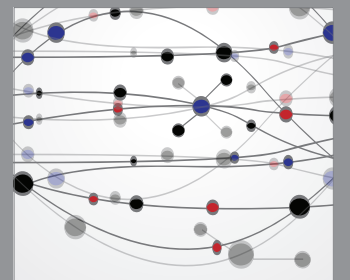

The Scientific World Journal
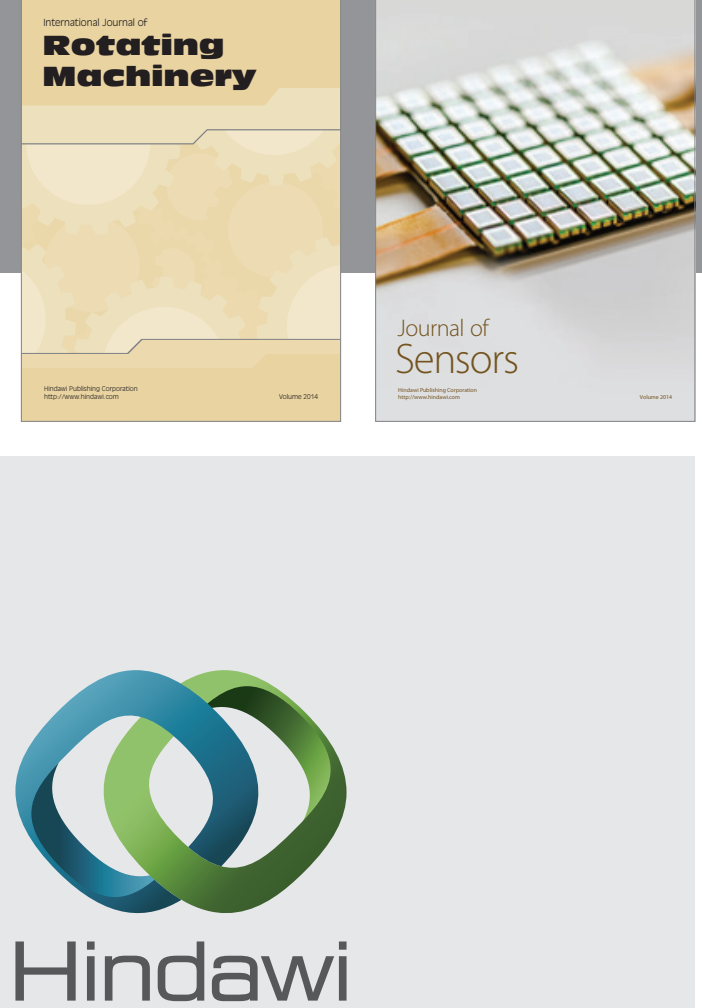

Submit your manuscripts at http://www.hindawi.com
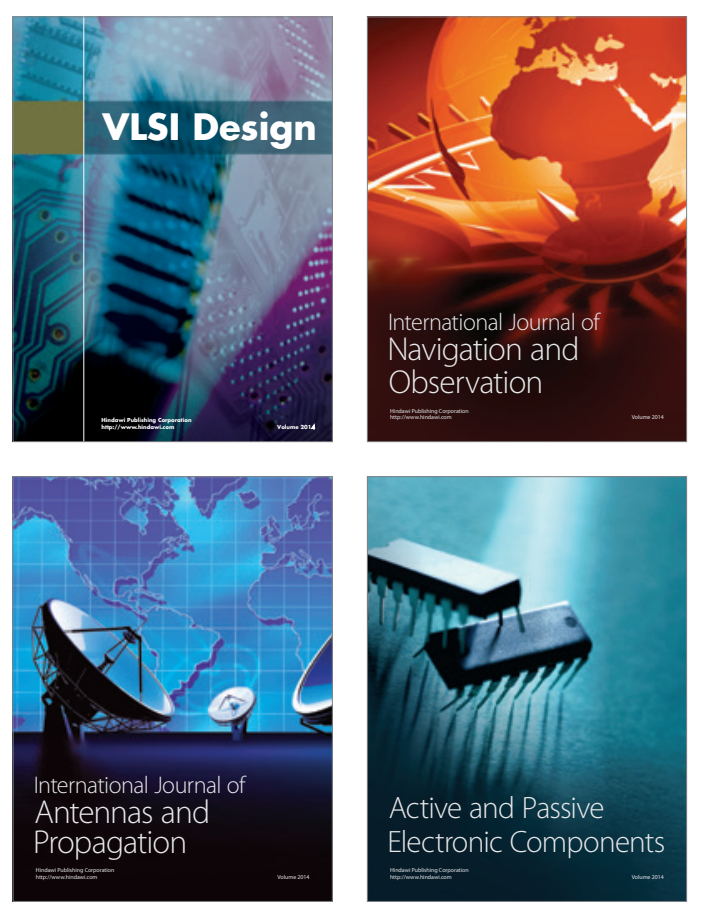
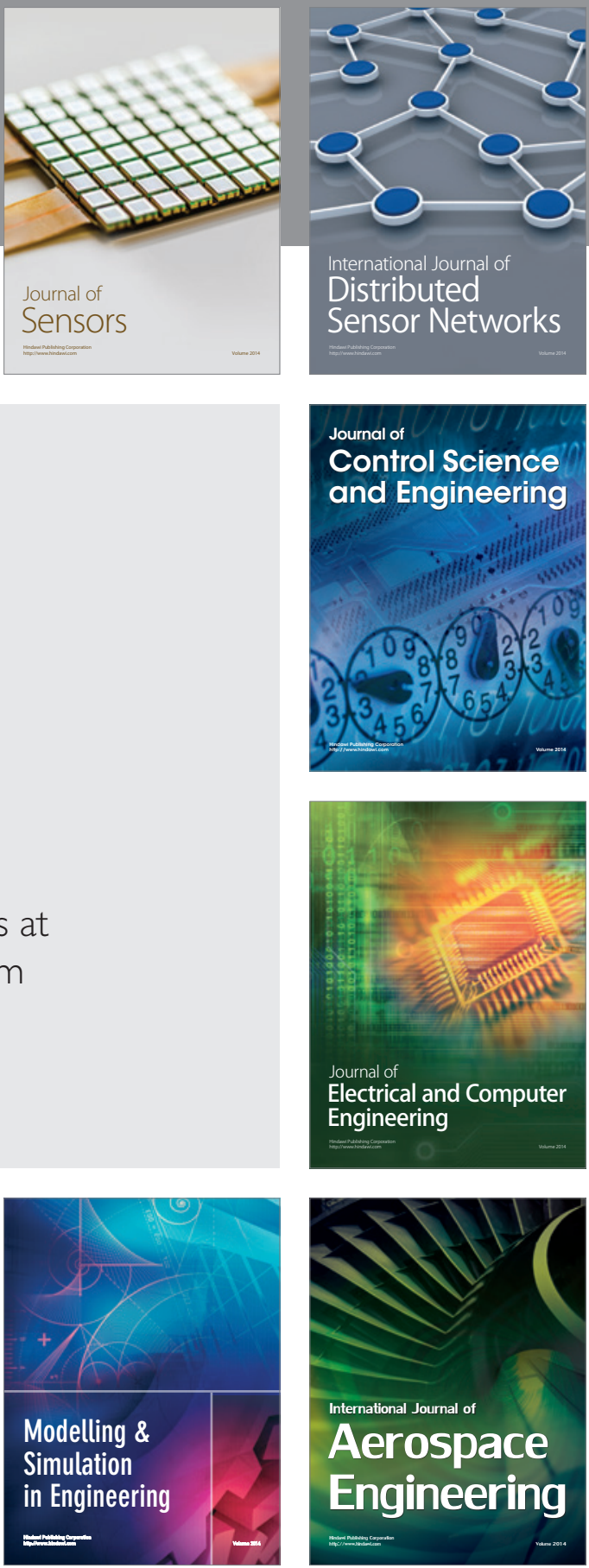

Journal of

Control Science

and Engineering
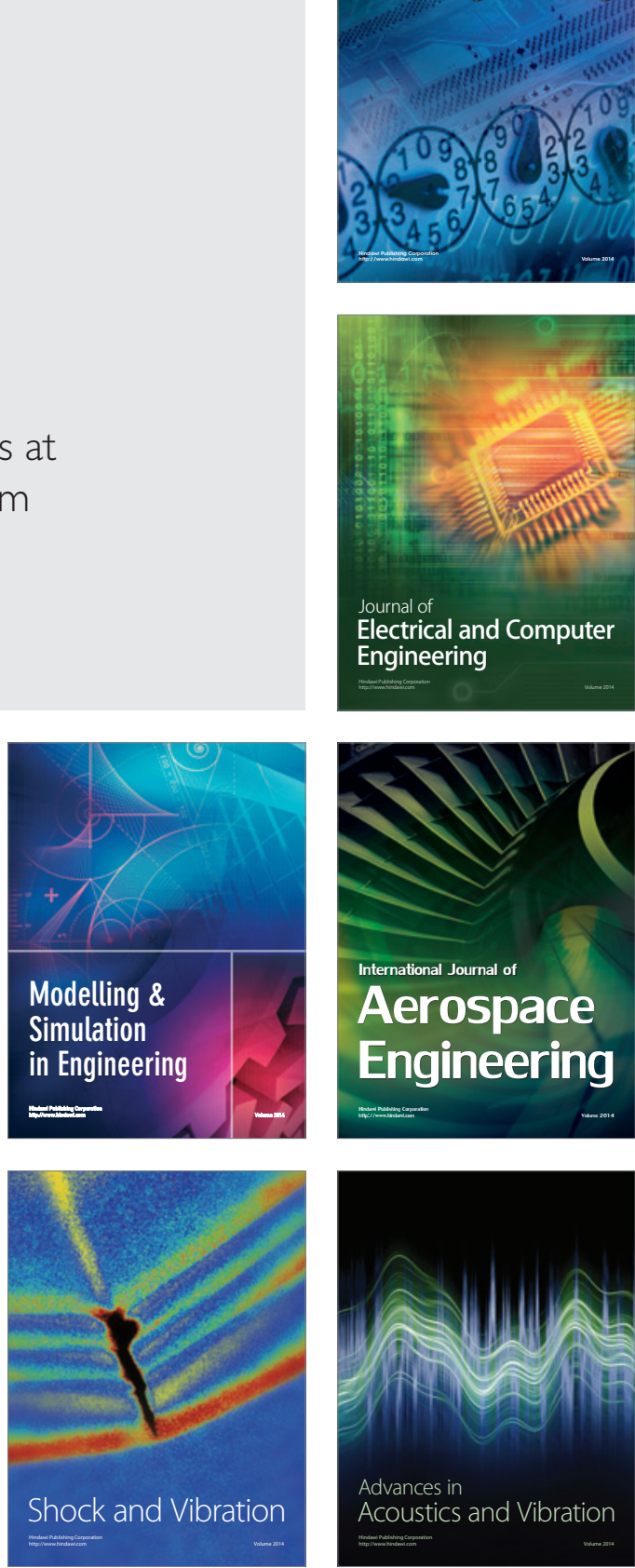